\title{
Speak Out Students! Why Don't You Attend English Classes?
}

\author{
Pauline Ghenghesh \\ Department of English Language, the British University in Egypt, El Sherouk City, Cairo, Egypt \\ Email: paulineghenghesh@yahoo.co.uk \\ Nabila Louis Nakhla \\ Department of English Language, the British University in Egypt, El Sherouk City, Cairo, Egypt
}

\begin{abstract}
This paper aims to focus on the reasons why students do not to attend English classes, and linking this to performance. Data were gathered from three sources: (1) a student questionnaire, (2) a round of semistructured interviews and (3) attendance records and end of semester grades. The results indicated a number of reasons for non-attendance to include: workload in the faculty, the duration of the classes, time of the day, uninteresting and unchallenging classes, and irrelevant material and writing tasks. A significant positive relationship between attendance and grades was also found.
\end{abstract}

Index Terms — student attendance, grades, duration of classes, uninteresting classes

\section{INTRODUCTION}

Student attendance is a topic that is widely discussed amongst academics worldwide and in particular those working in Higher and Further Education institutions. A review of the literature has shown that relatively little research has been done at universities in Western countries and to the authors' knowledge no study has been published in the Arab world to investigate the fundamental reasons for student non-attendance at lectures or classes. Anecdotal evidence suggests that student attendance at English classes at the British University in Egypt has been on the decline for a number of years. Although teachers tend to make assumptions as to why students do not attend classes, prior to this study, no empirical research had been conducted to examine the reasons for non-attendance or to investigate whether there is a relationship between attendance and performance. Since English is the medium of instruction at the university and all students are required to take English modules in order to support them in their degree areas, this research sets out to examine why students do not attend English classes and linking this to performance.

\section{REVIEW OF THE LITERATURE ON NON-ATTENDANCE}

From the available published research findings 'work on other assignments' has tended to rank high in the reasons given for not attending lectures. The results of a study at Lincoln University found that $40 \%$ of the reasons given for non-attendance at lectures were the pressure of other learning tasks (Fleming, 1995). For Hunter and Tetley (1999) it ranked as the number one reason in their UK study with $43 \%$ of students claiming to miss lectures because of it. In another study conducted in the UK, it has also been reported as high as $61 \%$ and ranked as the second most prominent reason for missing lectures (Kottasz, 2005). Similarly, it ranked second for 32\% of students at a Scottish University (Paisey \& Paisey, 2004) and third by 51\% of students in Australia (Pithers \& Holland, 2007).

The 'timing of the class' also has an impact on student attendance. Fifty percent of Kottasz (2005) respondents claimed that inconvenient lecture times were reasons for missing lectures while other researchers reported 20\% (Hunter \& Tetley, 1999) and 16\% (Fleming, 1995). Findings have shown that classes scheduled from 10 a.m. to 3 p.m. will have better attendance (Paisey \& Paisey, 2004; Devadoss \& Foltz, 1996). Furthermore, the 'length of the class' is also a factor that some students see as a reason for non-attendance. It has been reported that students may prefer a shorter lecture (50 minutes) three times per week over a longer lecture (75 minutes) given twice a week (Devadoss \& Foltz, 1996).

Classes which are considered to be 'boring', 'a waste of time', and 'unnecessary' can have a strong effect on student motivation and attendance. Results indicate that if students find the lectures and material boring, they will more than likely not attend (Kottasz, 2005; Romer, 1993; Fjortoft, 2005, Devadoss \& Foltz, 1996; Hunter \& Tetley, 1999; Massingham \& Herrington, 2006). Poor lecturing was also found to be an important factor for non-attendance (Fleming 1992; Kottasz, 2005). Along similar lines, uninteresting and unclear lecturers ranked as the second most important factor for non-attendance in Pithers and Holland (2007) study. 'Unchallenging classes' was another factor that has a significant impact on the percentage of lectures that students attend (Hunter \& Tetley, 1999; Kottasz, 2005; Dolnicar, Kaiser, Matus \& Vialle, 2009). 
Other important factors with varying response rates are 'transport/parking problems' ranging from 7\% (Hunter \& Tetley, 1999) to $61 \%$ (Kottasz, 2005). 'Illness/family problems' accounting for 14\% of Hunter \& Tetley's (1999) responses, 37\% of Pithers \& Holland's (2007) business students, about 26\% of Paisey \& Paisey's (2004) accounting students and as high as $72 \%$ for Kottasz (2005) study. 'Employment commitments' was $6 \%$ of the reasons given by Hunter \& Tetley's (1999) students and was the most frequently cited reason for missing classes in Paisey \& Paisey’s (2004) study. 'Two or more hour breaks' before or after a class was another reason found for not attending class (Fjortoft, 2005).

\section{A. Does Attendance Improve Performance?}

Several studies provide strong empirical evidence that there is a relationship between attendance and grades. The findings of these studies are fairly consistent, regardless of the country, course, university and students. Romer's (1993) study in economics classes at three elite US universities found that students who attend only a quarter of the lecturers on average earned a C- grade, while a student who attends all lectures earned a B+. Other researchers (Devadoss \& Foltz, 1996; Paisey \& Paisey 2004; Gendron \& Pieper, 2005; Thatcher, Fridjhon \& Cockcroft, 2007; Massingham \& Herrington, 2006; Ajiboye \& Tella, 2006) found similar results from studies conducted at US, UK, Canadian, Botswanan, Australian \& South African Universities. The more classes a student attends the better the student's grade. Similarly, LeBlanc III, (2005) compared the attendance records of students against their test score averages at four institutions over a fourteen year period and found that attendance significantly influences test score averages whether or not an attendance policy is enforced.

This study adds to the existing literature on non-attendance by investigation the reasons why students do not attend English classes and linking this to performance. The main aim of the present study is to examine the reasons for nonattendance at English classes.

1. What are the perceived reasons for non-attendance at English classes?

2. Does a relationship exist between attendance and performance?

\section{B. The Setting}

At the British University in Egypt (BUE) English is the medium of instruction in all faculties and departments. There is a Department of English which acts as a support centre for all students in the different faculties. There are five levels of English: Pre-Intermediate, Intermediate, Upper Intermediate, Advanced and Advanced Writing. The Advanced and Advanced Writing modules are compulsory for all students to take.

Students sit for a placement test upon entry to the BUE and are placed in one of the English levels according to the score they obtain. The placement test consists of two components: Listening and Grammar. Students must follow the sequence of modules to progress through the levels. Each module must be successfully completed before moving to the next level. Students must score Pre-Intermediate on the placement test which is equivalent to 3 on IELTS in order to enter the degree area. Furthermore, students must take English modules alongside degree area modules and must complete them before graduating.

During the academic year 2009/2010 Pre-Intermediate and Intermediate were one-year long modules consisting of 48 contact classes and 52 hours of independent learning per semester. The Upper Intermediate, Advanced and Advanced Writing modules were 48 contact classes and 52 hours of independent learning over the course of one semester. Classes were two hour sessions twice a week and the number of students in each group varied from 15 to 30 .

\section{RESEARCH METHODOLOGY}

\section{A. Participants}

The participants in this study were 727 undergraduate students studying in the faculties of Engineering, Informatics and Computer Science, Nursing, and Business (including Business Administration, Economics and Political Science) at the British University in Egypt (BUE). All students completed a questionnaire survey during the last two weeks of semester one, 2009.

Fifty students were invited to take part in a semi-structured interview in semester two. Ten students were selected from each of the five English levels: Pre-Intermediate, Intermediate, Upper Intermediate, Advanced and Advanced Writing. Students were chosen according to the following criteria:

- They were either repeating the module, or had less than $50 \%$ attendance in semester one.

-They were available at the time of the interviews.

\section{B. Instruments}

Data were collected using both quantitative and qualitative methods and based on those factors which the authors considered likely to be most important to the students as possible reasons for non-attendance at their English classes. In all, a total of two research instruments were devised for this study: a short questionnaire and semi-structured interviews for students. In addition to this, the attendance sheets were provided by those teachers that kept attendance records throughout the semester and the students' grades were obtained from the module board reports for semester one. 
The researchers obtained written permission to carry out this research, administer the questionnaire and conduct the interviews on the chosen sample from the Research Committee in the English Department at the British University in Egypt.

The investigation consisted of two stages. For the initial stage the questionnaire was administered to the students by the researchers with the assistance of the class teachers during regular class time. The researchers asked teachers to explain to students the rationale for the questionnaire. All students were willing to complete the questionnaire and only a very small percentage (1.3\%) was incomplete and therefore not used. The completed questionnaires were collected by the teachers and handed to the researchers for analysis. The questionnaire took about 10 minutes to complete and students were not asked for personal details such as name and ID number.

The main part of the questionnaire consisted of 14 reasons for non-attendance which required students to respond to the items by simply ticking a box. There were also two open-ended questions and a statement which provided the students with the opportunity to include their own ideas on how the English department can help them attend all their classes, to give additional reasons for non-attendance and for those that do attend one hundred percent of their classes to say why. The questionnaire also sought to obtain some background information about the students.

For the second stage of data collection 50 semi-structured interviews (about 20 minutes) were conducted, recorded and analysed to establish the reasons for non-attendance and to enable students to speak about their own experiences and provide additional information on this topic. Students were asked individually if they would like to assist the researchers by taking part in this study. The interviews were conducted towards the end of semester two during the students' free time. The interview questions for students are as follows:

1. How long have you been studying at the BUE?

2. When you joined the BUE which English module were you placed in?

3. Have you repeated English modules? If yes, which ones? Why?

4. If you miss English classes, why?

5. How do you make-up for missed classes?

6. How can the English department encourage students to attend classes?

\section{Data Analysis}

The data obtained from the questionnaire was computer coded and processed with the Statistical Package for the Social Sciences (SPSS) version 13.0. Student grades and attendance were also analysed using the SPSS. Secondly, a correlational analysis using Pearson Product-Moment Correlations was conducted to identify the interrelationship between the students' grades and attendance to examine the relationship between these two variables.

The semi-structured interviews were tape-recorded and transcribed. Notes were taken of student's answers and were listed in specific descriptive phrases that could be easily read and counted. At the end of the analysis there was one complete table for each student illustrating the responses to the questions. In addition to this, notes were taken of student's individual comments that were considered to be significant and would further assist in understanding their reasons for non-attendance. These were written on the back of their tables.

\section{E. Findings}

\section{Questionnaire}

Do you attend all your English classes?

Rather than ask students to estimate their percentage of attendance or absence throughout the semester, they were asked whether they attend all their English classes. Overall, 67.7\% (492/727) of students said they did not attend all their classes as opposed to $32.3 \%$ (235/727) who said they did.

Reasons for non-attendance at English classes

The findings of the present study show that the most prominent reason given by students for non-attendance to English classes was because they needed to work on assignments and projects for subjects in their faculties (49.4\%). Along similar lines was the third ranked factor which was that students missed English classes to revise for midsemester exams in degree area subjects $(38.2 \%)$.

The second ranked factor for missing English classes was because of the duration of the teaching sessions which were two hours (38.8\%). The fourth ranked factor is the perception that English classes are not interesting (21.8\%) while the fifth ranked factor is the wrong timing of classes which were at the end of the day from $2-4(21.1 \%)$. Other reasons given for not attending all English classes are shown in Table 1. 
TABLE 1.

REASONS FOR NON-ATTENDANCE AT ENGLISH CLASSES

\begin{tabular}{|c|c|c|c|}
\hline Reasons for non-attendance & $\begin{array}{l}\text { No. of students } \\
(n=492)\end{array}$ & $\%$ & Rank order \\
\hline I do not have time because of assignments and projects for my faculty & 243 & 49.4 & 1 \\
\hline Length of class is too long ( 2 hours) & 191 & 38.8 & 2 \\
\hline I do not have time because of mid-semester exams for my faculty & 188 & 38.2 & 3 \\
\hline Classes are not interesting & 107 & 21.8 & 4 \\
\hline The 2 - 4 teaching session is not suitable & 104 & 21.1 & 5 \\
\hline I can pass English modules without attending all classes & 86 & 17.5 & 6 \\
\hline Illness \& too tired & 73 & 14.8 & 7 \\
\hline The material is not relevant to my degree area & 64 & 13.0 & 8 \\
\hline English is not very important for my faculty & 46 & 9.4 & 9 \\
\hline Material is available on BUE E-learning site & 44 & 8.9 & 10 \\
\hline Class attendance is not compulsory & 42 & 8.5 & 11 \\
\hline I take material and information from friends & 42 & 8.5 & 11 \\
\hline There are no credits for English modules & 37 & 7.5 & 12 \\
\hline I cannot understand lessons & 30 & 6.1 & 13 \\
\hline The teacher is unhelpful & 21 & 4.3 & 14 \\
\hline
\end{tabular}

Reasons for attending all English classes

With regard to the students who attend all their English classes, they were asked to give the reasons for this. The major reason given by more than $60 \%$ of the students was to improve their English proficiency. Table 2 shows other reasons given by the students for attending all English classes.

TABLE 2.

REASONS FOR ATTENDING ALL ENGLISH CLASSES

\begin{tabular}{|l|l|l|l|}
\hline Reasons for attendance & $\begin{array}{l}\text { No. of students } \\
(\boldsymbol{n = 2 3 5})\end{array}$ & \% & Rank order \\
\hline To improve my English & 144 & 61.3 & 1 \\
\hline To progress to the next English module & 31 & 13.2 & 2 \\
\hline English is important \& useful & 26 & 11.1 & 3 \\
\hline I enjoy the subject & 25 & 10.6 & 4 \\
\hline To gain marks & 24 & 10.2 & 5 \\
\hline The class \& teacher are interesting & 19 & 8.1 & 6 \\
\hline Attendance is taken for each class & 10 & 4.3 & 7 \\
\hline I can understand the lessons & 10 & 4.3 & 7 \\
\hline To keep up & 5 & 2.1 & 8 \\
\hline I have friends in the same class & 2 & 0.8 & 9 \\
\hline The number of students in the group is small & 1 & 0.4 & 10 \\
\hline
\end{tabular}

In your opinion, what can the English Department do to help you attend all your classes?

The last consideration of the questionnaire for this study was to elicit the opinions of students on how the English Department can help students attend all their classes. More than 24\% (177/727) of students responded that making the lessons fun, interesting, varied, useful and challenging will help them attend all their classes.

2. Interviews

How long have you been studying at the BUE?

From the analysis of the first interview question the number of interviewed students and years they have been studying at the BUE are shown in Table 3.

TABLE 3.

NUMBER OF STUDENTS AND YEARS STUDIED AT THE BUE

\begin{tabular}{|l|l|}
\hline No. Students & No. Years at BUE \\
\hline 16 & 1 year \\
\hline 16 & 2 years \\
\hline 6 & 3 years \\
\hline 9 & 4 years \\
\hline 3 & 5 years \\
\hline
\end{tabular}

When you joined the BUE, which English module were you placed in? Have you repeated any English modules? If yes, which ones? Why?

The emerging patterns from Questions 2 and 3 of the interviews are shown in Table 4. The majority of interviewed students (31/50) have repeated English modules with a number of students (10) having repeated more than one module. All students attributed repeating English modules to poor attendance. 
TABLE 4.

MODULE PLACEMENT, NUMBER OF STUDENTS AND TIMES REPEATED ENGLISH MODULES

\begin{tabular}{|c|c|c|c|c|}
\hline Module placement & No. of Students & $\begin{array}{l}\text { English Modules } \\
\text { Repeated }\end{array}$ & $\begin{array}{l}\text { No. of Students Repeated } \\
\text { English Modules }\end{array}$ & $\begin{array}{l}\text { No. of times Students } \\
\text { Repeated English Modules }\end{array}$ \\
\hline Pre-intermediate & 18 & Pre-intermediate & 2 & 1 time $(2 \mathrm{Ss})$ \\
\hline Intermediate & 16 & Intermediate & 5 & 1 time $(5 \mathrm{Ss})$ \\
\hline Upper Intermediate & 12 & Upper Intermediate & 13 & $\begin{array}{l}1 \text { time }(10 \mathrm{Ss}) \\
5 \text { times }(1 \mathrm{~S}) \\
6 \text { times }(1 \mathrm{~S}) \\
8 \text { times }(1 \mathrm{~S})\end{array}$ \\
\hline Advanced & 4 & Advanced & 11 & $\begin{array}{l}1 \text { time }(5 \mathrm{Ss}) \\
2 \text { times }(1 \mathrm{~S}) \\
3 \text { times }(1 \mathrm{~S}) \\
4 \text { times }(2 \mathrm{Ss}) \\
8 \text { times }(1 \mathrm{~S}) \\
10 \text { times }(1 \mathrm{~S})\end{array}$ \\
\hline Advanced Writing & 0 & Advanced Writing & 10 & $\begin{array}{l}1 \text { time }(3 \mathrm{Ss}) \\
3 \text { times }(2 \mathrm{Ss}) \\
4 \text { times }(2 \mathrm{Ss}) \\
5 \text { times }(2 \mathrm{Ss}) \\
6 \text { times }(1 \mathrm{~S})\end{array}$ \\
\hline
\end{tabular}

Did you attend 100\% of your English classes last semester? If not, why?

In order to determine why all the interviewed students did not attend all their English classes last semester, the aim of Q. 4 of the interview was to elicit the possible reasons for this. Amongst the reasons for missing English classes are: classes and materials were considered to be uninteresting (60\%); workload and mid-semester exams in the faculties (54\%) and because of the $2-4$ teaching session (42\%). Other reasons given for missing classes are shown in Table 5 .

TABLE 5.

REASONS FOR NOT ATTENDING ENGLISH CLASSES

\begin{tabular}{|l|l|l|l|}
\hline Reasons for non-attendance & $\begin{array}{l}\text { No. of students } \\
(\mathbf{n = 5 0 )}\end{array}$ & $\mathbf{\%}$ & Rank order \\
\hline Classes \& material were not interesting & 30 & 60 & 1 \\
\hline Workload \& exams in the faculty & 27 & 54 & 2 \\
\hline The 2 - 4 teaching session was not suitable & 21 & 42 & 3 \\
\hline The material was not relevant to my degree area & 18 & 36 & 4 \\
\hline Illness & 12 & 24 & 5 \\
\hline Length of class was too long (2 hours) & 12 & 24 & 5 \\
\hline Classes \& material were not challenging & 10 & 20 & 6 \\
\hline
\end{tabular}

How do you make-up for missed classes?

In response to Question 5 which focused on eliciting from students how they made-up for missed classes, the results of this analysis revealed that $40 \%$ of the students did nothing at all while $30 \%$ either checked what material had been uploaded on e-learning or asked the teacher to inform them what had been covered in class (See Table 6).

TABLE 6.

MAKING UP FOR CLASSES

\begin{tabular}{|l|l|l|l|}
\hline Making-up for missed classes? & $\begin{array}{l}\text { No. of students } \\
(n=50)\end{array}$ & $\%$ & Rank order \\
\hline Didn't make up for missed classes & 20 & 40 & 1 \\
\hline Checked material on e-learning & 15 & 30 & 2 \\
\hline Asked teacher what was missed & 15 & 30 & 2 \\
\hline Asked friends what was taken & 14 & 28 & 3 \\
\hline Got photocopied material from copy centre & 2 & 4 & 4 \\
\hline Photocopied sheets from students & 2 & 4 & 4 \\
\hline
\end{tabular}

How can the English Department encourage students to attend classes?

The first ranked factor cited by $60 \%$ of the students as a motivator for class attendance was that the classes (including the material, activities and writing topics) should be interesting. The second ranked factor elicited by $40 \%$ of the students was to introduce relevant material and writing topics as well as having no teaching sessions during afternoon slots from $2-4$. 
TABLE 7.

MOTIVATIONAL FACTORS RELATED TO ATTENDANCE

\begin{tabular}{|l|l|l|l|}
\hline Motivators for class attendance & $\begin{array}{l}\text { No. of students } \\
(\mathbf{n = 5 0 )}\end{array}$ & $\mathbf{\%}$ & $\begin{array}{l}\text { Rank } \\
\text { order }\end{array}$ \\
\hline Interesting classes / material / activities / topics & 30 & 60 & 1 \\
\hline Introduce relevant material \& writing topics & 20 & 40 & 2 \\
\hline No 2 - 4 teaching session & 20 & 40 & 2 \\
\hline More support from teachers & 13 & 26 & 3 \\
\hline Reduce teaching sessions to one-hour & 13 & 26 & 3 \\
\hline More challenging classes \& material & 13 & 26 & 3 \\
\hline More focus on speaking \& oral presentations & 11 & 22 & 4 \\
\hline $\begin{array}{l}\text { Coordination between faculties / departments with } \\
\text { timetable / mid-semester exam / workload }\end{array}$ & 11 & 22 & 4 \\
\hline Place students correctly in English modules & 9 & 18 & 5 \\
\hline Credits for all English modules & 5 & 10 & 6 \\
\hline Reduce workload of advanced writing module & 5 & 10 & 6 \\
\hline
\end{tabular}

\section{RESULTS}

Correlational analyses of students' attendance and grades

Intermediate, advanced $\&$ advanced writing modules

Although the first analysis involved testing the relationship between attendance and grades for combined cohorts $(\mathrm{N}=341)$ consisting of intermediate, advanced and advanced writing students there was no attendance policy during semester one, 2009 and contact hours as well as testing procedures within the different modules were consistent. The correlation test revealed a significant positive relationship between attendance and grades with a correlation coefficient of $.63(p<0.01)$.

Given the concern that student bodies may have considerably different characteristics between English modules, the researchers also tested for a relationship among students by English modules. The correlation tests for the intermediate module $(\mathrm{N}=176)$ revealed a significant positive relationship between attendance and grades. The correlation coefficient for the sample was .61 $(p<0.01)$.

The correlation tests for the advanced module $(\mathrm{N}=88)$ showed a stronger positive relationship between attendance and grades $.74(p<0.01)$ compared with the intermediate module. For the advanced writing module $(\mathrm{N}=77)$ correlation tests revealed a positive relationship between attendance and grades with a correlation coefficient of .70 $(p<0.01)$. A comparison of student cohorts revealed some differences. The two higher English modules (advanced and advanced writing) showed a relatively higher correlation compared with the intermediate.

\section{DISCUSSION}

The results of this research clearly indicate that the students who took part in this study absented themselves from English classes for a variety of reasons. The most common reason was the need to work on assignments and projects in the faculties. Linked with this was the need to miss classes to revise for mid-semester exams in the faculties. These responses suggest that students' regard English as being a burden since it is an additional subject which is compulsory for them to take alongside their degree area subjects. Students comments included: "There's not enough time to study English and degree area subjects;" "Difficult modules in the degree area," "Because there should be no English classes the same day as mid-semester exams in the faculty." Working on assignments and study commitments have been important issues found in other studies (Fleming, 1995; Hunter \& Tetley, 1999; Kottasz, 2005; Paisey \& Paisey, 2004; Pithers \& Holland, 2007).

The two hour teaching session is also another prominent factor for missing English classes. All teaching sessions at the university, whether lectures or classes are two hours duration. Students move from one two hour lecture or class to another throughout the day and therefore regard it as being 'too long', 'tiring' and 'boring'. One student highlights this by saying: "Two hours is too long, three sessions one hour each would be better." This finding is in accordance with other research findings as Devadoss \& Foltz, (1996) did find with their US sample that students may prefer shorter lectures (50 minutes) over longer ones (75 minutes).

The timing of the classes is also another factor for non-attendance. Lectures and classes at the university start at 9 a.m. and finish at 4 p.m. five days a week. The last teaching session of the day is from $2-4$ p.m. However, students prefer to finish classes by 3:00 p.m. to avoid the rush hour traffic so that they can return home at a reasonable hour to work on assignments and projects for their faculties. Students expressed their opinions on this issue by saying: "I leave early to go home and work on projects for the faculty;" "I leave early to avoid the traffic;" "Change the time of the class. Have earlier classes."

This finding mirrors those of other research findings (Kottasz, 2005; Hunter \& Tetley, 1999; Fleming, 1995). Fifty percent of Kottasz (2005) respondents said that inconvenient lecture times were reasons for missing lectures. Findings have shown that classes scheduled from 10 a.m. to 3 p.m. will have better attendance (Paisey \& Paisey, 2004; Devadoss \& Foltz, 1996). 
Another major reason cited by the students as a motivator for class attendance was uninteresting classes. Students mentioned that the classes should be 'fun'; 'interesting' and 'varied'. This is how some students expressed their feelings towards the English classes: "Make it more interesting, classes are boring to death;", Give more interesting topics;" "Make the classes more communicative." Earlier studies have found similar results (Kottasz, 2005; Romer, 1993; Fjortoft, 2005; Devadoss \& Foltz, 1996; Hunter \& Tetley, 1999).

Unchallenging classes is another factor for non-attendance. At the BUE students are placed in English modules according to their English placement test score, whereas in the faculties students are placed in groups according to year and area of specialisation. Therefore, the material that is introduced to students in the English department accommodates their English level, whereas, students in their degree areas are required to read articles from academic books written with high standards of specialised English. As a result, students regard English as being 'too easy'. This is what students had to say about the English classes: "Classes are below my level;" "We need challenging material and tasks;" "We've taken these components at school," "I do not need to attend classes. I can pass modules by taking assessments and doing coursework." Furthermore, the results of the interviews showed that $40 \%$ of the students do not make up for missed classes. Unchallenging classes has also been a factor for student non-attendance in other studies (Hunter \& Tetley, 1999; Kottasz, 2005; Dolnicar, et al. 2009).

Another motivational factor for class attendance was the need for the English modules to introduce reading material and writing tasks that are appropriate to student and faculty needs. Amongst other things, students mentioned the need to write 'technical reports' instead of paragraph and essay writing. Students expressed their views on this issue: "The English we study is not relevant to my faculty," "The content of the syllabus is not helping me in my courses;" "It should give us materials and skills that will help us in the future."

The correlation tests suggest that attendance is related to grades. This finding is in-line with other studies that found that attendance has an impact on performance (Romer, 1993; Devadoss \& Foltz, 1996; Paisey \& Paisey 2004; Gendron \& Pieper, 2005; Thatcher, et al. 2007; LeBlanc III, 2005; Ajiboye \& Tella, 2006). Attendance at classes will be crucial for a subject like English, as it is a verbal-based subject that requires a lot of classroom based practice.

\section{CONCLUSION}

The current study was aimed at finding out why students miss English classes. The results of the quantitative data and qualitative interviews show that the reasons offered by students on non-attendance are in accordance with other studies conducted in different parts of the world. Although some factors are beyond the control of the teachers (timing and length of classes) most of the reasons found on non-attendance in this study may be influenced to a large extent by the teachers in the English department. For example, uninteresting, unchallenging and irrelevant classes as well as workload in the faculties are issues that teachers should address. These factors will have an important influence on students' motivation, attendance and performance. To have any hope of reversing this current trend on non-attendance teachers must change the way they teach and design their curriculum accordingly.

\section{RECOMMENDATIONS}

It is recommended that the important findings of this research be fed into the Department of English Annual Programme Review (APR) for the coming academic year (2010/2011) and thereafter. Furthermore, to help reduce the workload of students the English department can work collaboratively with the faculties to develop students' writing (technical reports, projects, and dissertations). Lecturers in the faculties can help students develop the content of their writing while teachers in the English department can assist with the writing process by developing the form (i.e. vocabulary, spelling, sentence structure and organisation of ideas). Cooperative teaching will reduce the workload of students, as less writing will be required of them, which in turn should result in a higher standard of written work. Furthermore, the English department and faculties can work together to select content-based reading material and topics, vocabulary, writing tasks and research projects to ensure that the material is interesting, challenging and relevant to student and faculty needs.

\section{REFERENCES}

[1] Ajiboye, J. O. \& Tella, A. (2006). Class attendance and gender effects on undergraduate students' achievement in a social course in Botswana. Essays in Education. Available online at: http://www.usca.edu/essays/vol18fall2006.html (accessed $12^{\text {th }}$ July, 2010)

[2] Devadoss, S. \& Foltz, J. (1996). Evaluation of factors influencing student class attendance and performance. American Journal of Agricultural Economics, 78: 499-507.

[3] Dolnicar, S. Kaiser, S. Matus, K. \& Vialle, W. (2009). Can Australian Universities take measures to increase the lecture attendance of Marketing students? Journal of Marketing Education, 31: 203-211.

[4] Fleming, N. (1992). Why don't they attend? Occasional Paper, Education Unit, Lincoln University.

[5] Fleming, N. (1995). Attendance: Why don't they attend? Part 2, Discussion paper, Education Unit, Lincoln University.

[6] Fjortoft, N. (2005). Students' Motivations for Class Attendance. American Journal of Pharmaceutical Education, 69: 107-112.

[7] Gendron, P. P. \& Pieper, P. (2005). Does attendance matter? Evidence from an Ontario ITAL. 
[8] Hunter, S. \& Tetley, J. (1999). Lectures. Why don't students attend? Why do students attend? Paper presented at the HERDSA Annual International Conference, Melbourne, 12-15 July.

[9] Kottasz, R. (2005). Reasons for Student Non-Attendance at Lectures and Tutorials: an analysis. Investigations in university teaching and learning, 2: 5-16.

[10] Le Blanc III, H. (2005). The relationship between attendance and grades in the college classroom. Paper presented at the $17^{\text {th }}$ annual meeting of the international academy of business disciplines, Pittsburgh Pennsylvania, $8^{\text {th }}$ April.

[11] Massingham, P. \& Herrington, T. (2006). Does attendance matter? An examination of student attitudes, participation, performance and attendance. Journal of University Teaching and Learning Practice, 3: 82-103.

[12] Paisey, C \& Paisey, N. J. (2004). Student attendance in an accounting module-reasons for non-attendance and the effect on academic performance at a Scottish university. Accounting Education, 13(Supplement 1): 39-53.

[13] Pithers, B. \& Holland, T. (2007). I'm too busy and they are just so boring! Students and lectures. Available online at: www.iutconference.org/2007/pdfs/Papers/Pithers.pdf (accessed 30 ${ }^{\text {th }}$ June, 2010).

[14] Romer, D. (1993). Do students go to class? Should they? Journal of Economic Perspectives, 7: 167-174.

[15] Thatcher, A. Fridjhon P. \& Cockcroft, K. (2007). The relationship between lecture attendance and academic performance in an undergraduate psychology class. South African Journal of Psychology, 37: 656-660.

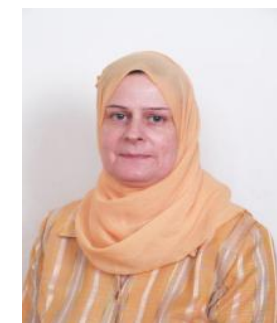

Pauline Ghenghesh was born in Liverpool, U.K. in 1959. She completed her $\mathrm{PhD}$ in 2005 in the area of motivation related to teaching and learning from the University of Nottingham in the U.K.

She has teaching experience at primary, secondary, high school, undergraduate and postgraduate levels in various parts of the world, including Brazil, Libya, the U.K., Egypt and Saudi Arabia. She currently holds the position of Lecturer at the British University in Egypt. She has published articles and books. Amongst them are three textbooks: English for Medical Students, ELGA Publications, 1996; Basic English for Children (1), General Company for Paper and Printing, Tripoli, 2001; Basic English for Children (2), Al An Printing and Publishing, Lebanon, 2004.

Dr. Ghenghesh's main research interests include student and teacher motivation, ESL writing, teacher development and materials development.

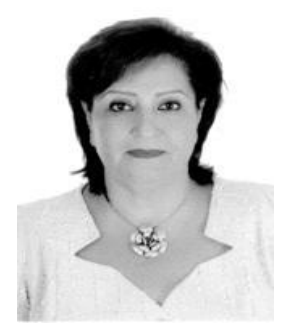

Nabila Louis Nakhla was born in Cairo, Egypt, in 1952. She completed her first MA in 1997 from the American University in Cairo in the area of TEFL and her second MA in 1983 from Leeds University in the UK in the same field.

She has over 30 years of experience in the area of linguistics and English language teaching. The first MA was related to motivation and the second one was a collocation and contrastive study on the use of verbs in Arabic and English. She has teaching experience with the Faculty of Education Ain Shams University, Cairo, the American University in Egypt and Ajman University in the UAE where linguistics, phonetics and English were taught. She presented papers at the International TESOL in California where she took accredited courses as well. She has written linguistic courses for Ajman University and participated in the phonetics, grammar, reading comprehension and listening books for Ain Shams University Center.

Mrs. Nabila's main research interests are in the area of English language teaching methodology, student motivation and English language testing. 